\title{
Occupancy of avian foraging guilds in soybean fields and borders in Entre Ríos, Argentina: responses to vegetation structure and prey resources
}

\author{
Andrea P. Goijman ${ }^{1,2^{*}}$ (D) Michael J. Conroy ${ }^{2,3}$, Vanina D. Varni ${ }^{1,4}$, Jeffrey J. Thompson ${ }^{1,5,6,7}$ \\ and María Elena Zaccagnini ${ }^{1,8}$
}

\begin{abstract}
Background: Reconciling agriculture and biodiversity conservation is a challenge given the growing demand for agricultural products. In recent decades, Argentina has witnessed agricultural expansion and intensification affecting biodiversity and associated ecosystem services. Within agroecosystems, the level of habitat quality is critical for birds, and may depend on vegetation structure, availability of invertebrate prey, and the use of pesticides. Although the relationship between vegetation structure and avian occurrence has been widely studied, to our knowledge, there are no studies that also incorporate prey availability throughout the cycle of soybean crops in Argentina. We estimated and predicted the effects of land cover and temporal variation on the occurrence of avian foraging guilds in Entre Ríos, Argentina, in order to guide management related to potential ecosystem services provided by birds. We also estimated temporal effects of vegetation structure and insecticides on the main arthropod orders consumed by birds to evaluate prey availability.
\end{abstract}

Methods: We conducted bird and arthropod surveys for 2 years along transects located in 20 randomly selected soybean fields $(N=60)$ and their adjacent borders $(N=78)$ throughout the crop growing season, in four seasons. We estimated avian occupancy, accounting for imperfect detection, and arthropod counts fitting generalized linear mixed models.

Results: The number of native trees in field borders positively influenced the occurrence of most bird species, mainly insectivores. Granivore foliage gleaners, also were positively affected by grass height. Salliers and aerial foragers were weakly affected by distance to forest and native trees. In general, the availability of invertebrates to birds was highest during the third season. Arthropod counts in borders were greater during the last three crop stages than during the pre-sowing period.

Conclusions: We found that with 10 to 15 native tree species in borders, coupled with a complex vegetation structure with shrubs and grasses, we could conserve a wide spectrum of insectivorous birds, and may contribute to the invertebrate pest control service. Vegetated field borders function as a refuge for arthropods, especially agriculturally

*Correspondence: goijman.andrea@inta.gob.ar

${ }^{1}$ Instituto de Recursos Biológicos, CIRN, Instituto Nacional de Tecnología

Agropecuaria (CNIA-INTA), Hurlingham, Buenos Aires, Argentina

Full list of author information is available at the end of the article

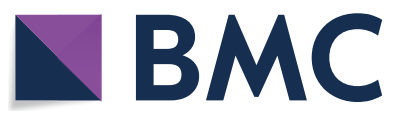

(c) The Author(s) 2020. This article is licensed under a Creative Commons Attribution 4.0 International License, which permits use, sharing, adaptation, distribution and reproduction in any medium or format, as long as you give appropriate credit to the original author(s) and the source, provide a link to the Creative Commons licence, and indicate if changes were made The images or other third party material in this article are included in the article's Creative Commons licence, unless indicated otherwise in a credit line to the material. If material is not included in the article's Creative Commons licence and your intended use is not permitted by statutory regulation or exceeds the permitted use, you will need to obtain permission directly from the copyright holder. To view a copy of this licence, visit http://creativeco mmons.org/licenses/by/4.0/. The Creative Commons Public Domain Dedication waiver (http://creativecommons.org/publicdomain/ zero/1.0/) applies to the data made available in this article, unless otherwise stated in a credit line to the data. 
beneficial taxa such as Hymenopterans. Finally, several groups of birds use the interior of the fields and could help control pests.

Keywords: Agriculture, Birds, Ecosystem services, Insecticide, Insectivores, Invertebrates, Management, Native trees, Occurrence

\section{Background}

Reconciling agriculture production and biodiversity conservation is a challenge given the growing demand for agricultural products. This demand has led to global intensification and expansion of agriculture, affecting biodiversity and associated ecosystem services (Foley et al. 2011; Tscharntke et al. 2012). In recent decades, Argentina, the third largest producer of soybeans, has witnessed agricultural expansion and intensification throughout the country (Paruelo et al. 2005; FAOSTAT 2013). In Argentina, the province of Entre Ríos occupies $2.8 \%$ of the country's land area and was responsible for $8 \%$ of its soybean production in 2007 , with most agricultural expansion replacing the original Espinal forest during the past 20 years (SIIA 2013). Given the rapid changes in land use in Entre Rios, reliable data are needed to inform decision-making concerning the management of agroecosystems to conserve ecosystem services while satisfying agricultural demands.

Birds serve as important ecological indicators and provide ecosystem services such as pest control (Kirk et al. 1996; Whelan et al. 2008; Kross et al. 2016). Bird species respond differently to agricultural land use at different scales (Codesido et al. 2008; Goijman and Zaccagnini 2008; Gavier-Pizarro et al. 2012; Goijman et al. 2015). Agricultural expansion and intensification alter many interrelated processes making it difficult to identify those factors that affect bird communities. Because the level of habitat quality is critical for species, the removal of field-scale features such as borders and use of pesticides may be key to avian conservation because they affect the availability and quality of shelter, nesting sites, and food resources (Wiens and Rotenberry 1981; Freemark and Boutin 1995; Krebs et al. 1999; Donald et al. 2006; Kirk et al. 2018). Understanding the effects of agricultural practices at a field-scale has important implications for avian conservation and the ecological services that birds provide (Kirk et al. 1996; Kross et al. 2016; Whelan et al. 2016).

The level of quality of field borders as habitat for birds may depend on vegetation structure, such as the presence of tall grasses, shrubs, and trees (Boutin et al. 1999; Jobin et al. 2001; Goijman and Zaccagnini 2008; Solari and Zaccagnini 2009; Di Giacomo and de Casenave 2010), as well as availability of invertebrate prey (Douglas et al. 2009). The drift of pesticides from adjacent agricultural fields may affect both (Boutin and Jobin 1998; Boutin et al. 1999). However, the results of studies in Entre Rios suggest that arthropod abundance in soybean borders was unaffected after insecticide applications and that, with judicious insecticide treatment, vegetated field borders can still support populations of avian insectivores (Weyland and Zaccagnini 2008; Varni 2010). Although the relationship between vegetation structure and avian occurrence has been widely studied, to our knowledge, there are no studies relating bird occurrence to vegetation structure together with availability of their prey resources throughout the cycle of soybean crops in Argentina. We intend to understand whether despite insecticide applications and their possible drift towards the borders, avian populations could persist. In addition, we want to provide information about the possible consequences of agricultural management practices on the provision of ecosystem services by birds in this region.

Our objective was to provide agricultural management recommendations focusing on potential ecosystem services provided by birds in Entre Ríos, Argentina. We estimated the effects of land cover and temporal variation on bird foraging guilds occurrence across our sampling frame. In addition, we examined temporal effects of vegetation structure and insecticides on the main arthropod orders consumed by birds to evaluate their availability as prey. We used occupancy models accounting for imperfect detection (MacKenzie et al. 2002, 2006; Tyre et al. 2003) to evaluate the influence of local vegetation covariates, invertebrate availability and distance to forests on birds in soybean fields and borders. We evaluated temporal effects only in soybean fields that are subject to rapid change. We did not evaluate this effect in borders because their structure remained mostly constant, and border management recommendations must encompass the whole season. In the first place, we predict that species using crops will be mainly ground foragers, and insectivores such as salliers and aerial foragers. In addition, we predict that the last two guilds will have higher probability of occurrence with increasing prey availability, which we expect to decrease with insecticide applications. In relationship to field borders, we predicted that for most avian groups higher quality of habitat (measured as green vegetation structure and food availability for insectivores), would increase occurrence, especially for gleaners that perceive landscape at small spatial scales 
and depend on nearby substrates (Goijman et al. 2015). However, we predict that more mobile species such as ground foragers, salliers, or aerial foragers, would be less dependent on vegetation structure.

\section{Methods}

Our study area consisted of 20 Soybean (Glycine max L. Merr.) fields and their adjacent borders near the towns of Cerrito, Palenque, María Grande, and El Pingo, in the north-central portion of the Paraná department in Entre Ríos province, Argentina ( $31.6665^{\circ} \mathrm{S}, 60.0365^{\circ} \mathrm{W}$; Fig. 1). Fields were randomly selected from a larger pool of available fields were we had permissions to carry out surveys and met minimum requirements described later. The area consisted of an agricultural landscape dominated by annual crops and grazing lands, where the expansion of row crop agriculture has rapidly led to the loss and degradation of native forest Calamari et al. (2018b). described this area as dominated by an agricultural matrix with $23 \%$ forest cover connected by corridors of riparian forest. The main crop was soybeans, with 184,500 ha sown in 2010-2011, representing 37\% of the department area (SIIA 2013). The original forest dominated landscape has been degraded and mixed with some exotic species as well. Trees in the study area have similar stands, and are mostly semi-deciduous or late deciduous species, which begin to regrow the foliage in September (Bortoluzzi et al. 2008; Aceñolaza pers. comm.). Originally, the area supported Espinal forest dominated by xerophytic woody species such as Prosopis affinis, Prosopis nigra, Acacia caven, Geoffroea decorticans, Celtis tala, and Schinus longifolia (Cabrera 1971; Burkart et al. 1999; Bortoluzzi et al. 2008). The climate is temperate and humid with abundant precipitation during spring and summer and a mean annual temperature of $18{ }^{\circ} \mathrm{C}$ and a mean annual rainfall of $\sim 1100 \mathrm{~mm}$.

\section{Data collection \\ Birds}

We conducted bird surveys for 2 years in 2-3 transects located in the center of each soybean field and 3-4 in their adjacent borders, where a greater number of transects could be allocated in larger fields. To ensure similar conditions we selected fields which previous crop in the rotation cycle was corn, and we excluded fields where there was a native forest on one of the sides. Surveys were

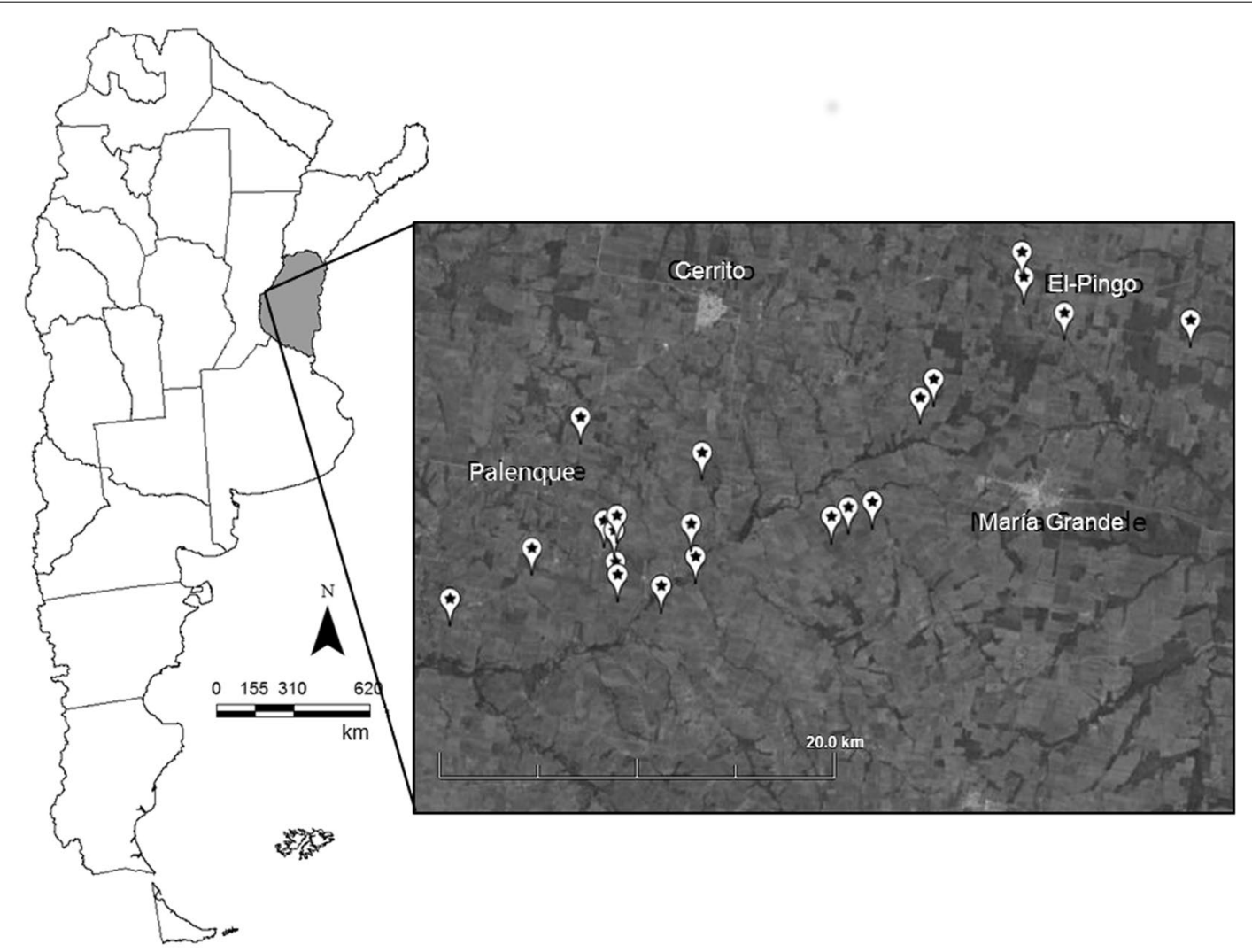

Fig. 1 Soybean fields where bird and arthropod sampling was conducted in 2007-2009, Paraná department, Entre Ríos, Argentina, near Cerrito, El Pingo, María Grande, and Palenque (GOOGLE EARTH 2013) 
conducted at four different stages throughout the soybean growing season in 2007-2008 and 2008-2009, coinciding with the austral spring and summer of the avian breeding season, and presence of migrants. The breeding season in this region begins in September for most species, when they start to establish their territories, and remain with stable territories until early March (Ralph et al. 1996). The first survey started beginning in midOctober prior to sowing, the second beginning in midDecember with soybean in the vegetative $(\mathrm{V})$ stage, the third survey at the end of January in the soybean reproductive stages (R), after blooming, and the last survey was prior to harvest at the beginning of March, after pod formation.

We surveyed birds along randomly allocated line transects of $200 \mathrm{~m}$ in field interiors within $50 \mathrm{~m}(N=60$, four seasons) and borders within $10 \mathrm{~m}$ of the field and the border natural vegetation ( $N=78$, four seasons) separated at least by $200 \mathrm{~m}$ to ensure independence of observations and avoid double counting (Boutin et al. 1999). We conducted surveys in the morning (06:00-09:00) when birds were most active, and all birds seen or heard using field border or interior were registered. Surveys were not conducted on days with rain or strong winds (Bibby et al. 2000).

\section{Arthropods}

We surveyed arthropods in the bird-sampling transects at the border and interior of soybean fields with two different methods each year to sample the largest number of groups with different habits (Standen 2000). Surveys were conducted between 14:00 and 16:00 when temperatures and arthropod activity were greatest (Hill 1980). During the first year of our study, we used sweep net to collect aerial and foliage arthropods, sweeping 25 times at four points every $50 \mathrm{~m}$ along each $200 \mathrm{~m}$ transect, pooling the samples per transect. During the second year, we collected arthropods using a vacuum (BR 420, Stihl, Waiblingen, Germany), to collect foliage and ground arthropods, during 40-s intervals at three points every $100 \mathrm{~m}$ and pooled the samples per transect.

All samples were stored in 70\% alcohol for later taxonomical classification. We identified arthropods to order for those orders most commonly detected in the diets of insectivorous birds: Araneae, Coleoptera, Diptera, Hemiptera, Hymenoptera, Lepidoptera, and Orthoptera (Alessio et al. 2005; Moorman et al. 2007; Capinera 2010).

\section{Field characteristics and vegetation}

We recorded field size, distance to the nearest forest patch, phenological stage of the crop, and insecticide applications on the fields, which were all sprayed. We recorded dates of application, products and concentrations. We considered three phenological stages of the crop, in addition to the pre-sawing season: vegetative stage $(\mathrm{V})$ and two reproductive stages (R) after blooming and after pod formation. At the borders, we measured width and counted the number of native and total trees along the 200-m transects. At two randomized points along each border transect, we measured visually grass height and estimated percent cover of five classes: herbaceous and dead vegetation, shrubs, trees, and bare soil. In the interior of the fields, we measured coverage of herbaceous vegetation, stubble, and bare soil visually in $1-\mathrm{m}^{2}$ plots. The same observer carried out visual estimations to maintain the same criteria.

\section{Statistical analyses}

We analyzed avian occurrence accounting for imperfect detection using an occupancy modeling framework that assumed that, if a species was not observed at a certain point, it can be either truly absent or present, but undetected (MacKenzie et al. 2002, 2006; Tyre et al. 2003). We used the package RMark (Laake 2013) in R 3.0.1 (R Core Team 2013) that provides a formula-based interface for MARK (White and Burnham 1999). We performed separate analyses for field interior and borders, using multiple group-single season occupancy models evaluating several covariates that could either affect detection or occupancy probabilities on a logit scale (MacKenzie et al. 2006). Because the number of detections was low for many species, we pooled species with $<10 \%$ detections. To pool species, we classified birds into nine guilds based on their foraging behavior and in the case of passerine granivores we also considered those which nest on the ground separately because they were very abundant (Table 1; Remsen and Robinson 1990; Azpiroz 2001; Beltzer 2003; De la Peña 2005). We are aware that a priori grouping could mask individual species responses associated with their species-specific traits (Philpott et al. 2009; Goijman et al. 2015).

We estimated occupancy $(\widehat{P s i})$ in field interiors for each season separately because we did not have a sufficient number of replicates to successfully implement multi-season models. We assumed that occurrence could differ by season given the development of the crop and the resulting changes in vegetation structure, in addition to direct insecticide applications. For inference on border management, we focused on the whole season. Field observations indicated that birds used the same borders the entire sampling period, which coincided with the breeding season and territories are stable, and thus assumed bird populations to be closed. Then we considered sampling periods as temporal replicates (for salliers and aerial foragers only considered seasons one to three because of the absence of 
Table 1 Species observed actively using soybean fields and borders from 2007 to 2009, Paraná department, Entre Ríos, Argentina

\begin{tabular}{|c|c|c|c|c|}
\hline Group (guild) $^{a}$ & Sub B (I) & Obs B (I) & Scientific name & Common name \\
\hline $\mathrm{GRD}^{1}$ & $g 1(g 1)$ & $63(186)$ & Vanellus chilensis & Southern Lapwing \\
\hline $\mathrm{GRD}^{1}$ & g1 (g2) & $6(32)$ & Bartramia longicauda & Upland Sandpiper \\
\hline $\mathrm{GRD}^{1}$ & g1 (g3) & $29(44)$ & Nothura maculosa & Spotted Nothura \\
\hline $\mathrm{COL}^{2}$ & $g 1(g 1)$ & $22(11)$ & Patagioenas maculosa & Spot-winged Pigeon \\
\hline $\mathrm{COL}^{2}$ & $g 1(g 1)$ & 3 & Patagioenas picazuro & Picazuro Pigeon \\
\hline $\mathrm{COL}^{2}$ & $g 1(g 1)$ & 17 & Leptotila verreauxi & White-tipped Dove \\
\hline $\mathrm{COL}^{2}$ & $g 2(g 1)$ & $325(37)$ & Columbina picui & Picui Ground Dove \\
\hline $\mathrm{COL}^{2}$ & g3 (g1) & $78(79)$ & Zenaida auriculata & Eared Dove \\
\hline GRAN $^{3}$ & g1 & 61 & Saltator aurantiirostris & Golden-billed Saltator \\
\hline GRAN $^{3}$ & g2 & 35 & Paroaria coronata & Red-crested Cardinal \\
\hline GRAN $^{3}$ & g2 & 1 & Microspingus melanoleucus & Black-capped Warbling Finch \\
\hline GRAN $^{3}$ & g2 & 27 & Poospiza nigrorufa & Black-rufous Warbling Finch \\
\hline GRAN $^{3}$ & g2 & 17 & Saltatricula multicolor & Many-colored Chaco Finch \\
\hline GRAN $^{3}$ & g2 & 7 & Sicalis flaveola & Saffron Finch \\
\hline GRGR $^{4}$ & $g 1(g 1)$ & $206(73)$ & Ammodramus humeralis & Grassland Sparrow \\
\hline $\mathrm{GRGR}^{4}$ & $g 2(g 1)$ & $396(24)$ & Zonotrichia capensis & Rufous-collared Sparrow \\
\hline$G_{R G R^{4}}$ & g3 & 16 & Embernagra platensis & Pampa Finch \\
\hline GRGR ${ }^{4}$ & g3 (g1) & $89(80)$ & Sicalis luteola & Grassland Yellow Finch \\
\hline $\mathrm{GRGR}^{4}$ & g3 & 4 & Volatinia jacarina & Blue-black Grassquit \\
\hline GRGR ${ }^{4}$ & g3 & 39 & Sporophila caerulecens & Double-collared Seedeater \\
\hline$G_{R G R^{4}}$ & g3 & 16 & Sporophila ruficollis & Dark-throated Seedeater \\
\hline $\mathrm{INS}^{5}$ & g1 & 78 & Troglodytes aedon & House wren \\
\hline $\mathrm{INS}^{6}$ & g2 & 58 & Mimus saturninus & Chalk-browed Mockingbird \\
\hline $\mathrm{INS}^{7}$ & g3 & 88 & Furnarius rufus & Rufous Hornero \\
\hline $\mathrm{INS}^{5}$ & g4 & 2 & Coccyzus melacoryphus & Dark-billed Cuckoo \\
\hline $\mathrm{INS}^{5}$ & g4 & 9 & Elaenia parvirostris & Small-billed Elaenia \\
\hline $\mathrm{INS}^{5}$ & g4 & 2 & Lathrotriccus euleri & Euler's Flycatcher \\
\hline $\mathrm{INS}^{5}$ & g4 & 6 & Euscarthmus meloryphus & Tawny-crowned Pygmy-tyrant \\
\hline $\mathrm{INS}^{5}$ & g4 & 17 & Geothlypis aequinoctialis & Masked Yellowthroat \\
\hline $\mathrm{INS}^{5}$ & g4 & 7 & Myiophobus fasciatus & Bran-coloured Flycatcher \\
\hline $\mathrm{INS}^{5}$ & g4 & 6 & Phacellodomus striaticollis & Freckle-breasted Thornbird \\
\hline $\mathrm{INS}^{5}$ & g4 & 1 & Phacellodomus sibilatrix & Little Thornbird \\
\hline $\mathrm{INS}^{5}$ & g4 & 11 & Polioptila dumicola & Masked Gnatcatcher \\
\hline $\mathrm{INS}^{5}$ & g4 & 15 & Schoeniophylax phryganophilus & Chotoy Spinetail \\
\hline $\mathrm{INS}^{5}$ & g4 & 13 & Serpophaga subcristata & White-crested Tyrannulet \\
\hline $\mathrm{INS}^{5}$ & g4 & 21 & Synallaxis albescens & Pale-breasted Spinetail \\
\hline $\mathrm{INS}^{5}$ & g4 & 1 & Synallaxis frontalis & Sooty-fronted Spinetail \\
\hline $\mathrm{INS}^{5}$ & g4 & 3 & Tapera naevia & Striped Cuckoo \\
\hline $\mathrm{INS}^{5}$ & g4 & 3 & Taraba major & Great Antshrike \\
\hline $\mathrm{INS}^{6}$ & g5 & 126 & Agelaioides badius & Bay-winged Cowbird \\
\hline $\mathrm{INS}^{6}$ & g5 & 55 & Molothrus bonariensis & Shiny Cowbird \\
\hline $\mathrm{INS}^{6}$ & g5 & 26 & Molothrus rufoaxillaris & Screaming Cowbird \\
\hline $\mathrm{INS}^{6}$ & g5 & 1 & Turdus rufiventris & Rufous-bellied Thrush \\
\hline $\mathrm{INS}^{6}$ & g5 & 3 & Turdus amaurochalinus & Creamy-bellied Thrush \\
\hline$A E R^{8}$ & $g 1(g 1)$ & $91(23)$ & Tyrannus savanna & Fork-tailed Flycatcher \\
\hline $\mathrm{AER}^{8}$ & g2 & 6 & Tyrannus melancholicus & Tropical Kingbird \\
\hline $\mathrm{AER}^{8}$ & g2 & $23(7)$ & Pitangus sulphuratus & Great Kiskadee \\
\hline$A E R^{8}$ & g2 & 4 & Pyrocephalus rubinus & Vermilion Flycatcher \\
\hline
\end{tabular}


Table 1 (continued)

\begin{tabular}{|c|c|c|c|c|}
\hline Group (guild) ${ }^{a}$ & Sub B (I) & Obs B (I) & Scientific name & Common name \\
\hline $\mathrm{AER}^{8}$ & 92 & 13 & Xolmis irupero & White Monjita \\
\hline$\overline{\mathrm{AER}^{9}}$ & g3 (g1) & $9(5)$ & Petrochelidon pyrrhonota & Cliff Swallow \\
\hline $\mathrm{AER}^{9}$ & g3 (g1) & $49(40)$ & Progne tapera & Brown-chested Martin \\
\hline $\mathrm{AER}^{9}$ & g3 (g1) & $1(4)$ & Tachycineta leucorrhoa & White-rumped Swallow \\
\hline
\end{tabular}

We indicate groups used for separate occupancy analysis: ground omnivores and insectivores (GRD), Columbiformes (COL), passerine granivores (GRAN), ground nesters passerine granivores (GRGR), insectivores (INS), and insectivorous aerial foragers and salliers (AER). We also indicate subgroups (g1, g2, g3, g4, g5) for analyses within each group, and total number of observations in field borders (B) and interior (I)

a Group (guild): 1 =ground omnivores; 2 =ground granivores; 3 =granivore foliage gleaners; 4 = ground nesting granivore foliage gleaners; $5=$ insectivorous foliage gleaners; $6=$ ground and foliage omnivores; $7=$ ground insectivores; $8=$ insectivorous salliers; $9=$ insectivorous aerial foragers

migrants in the fourth season). In addition, we based the assumption of closure on the fact that the main vegetation structure contributed mainly by shrubs and trees exhibited little change, and that the potential drift of insecticides to borders was found to not dramatically disturb arthropod abundance (Weyland and Zaccagnini 2008; Varni 2010). To support this assumption, we also evaluated arthropod counts throughout our study. Last, it is worth highlighting that occupancy models assume closure at a species and not an individual-level, then provided at least one individual is present in the unit at the time of a survey, the assumption will be met (MacKenzie et al. 2017).

We modeled detection $(p)$ accounting for the plausible effects of minimum temperature, and wind as covariates for most groups, and added a group effect with interactions in cases where we achieved a sufficient number of observations. In addition to modelling detection in field borders, we explored the effects of grass height, the total number of trees, and season.

We modeled occupancy both in field interior and borders with distance to the nearest forest for more mobile groups (i.e., Columbiformes, aerial foragers, and salliers), arthropod availability (only for those groups of birds with insectivorous diets), herbaceous vegetation height in borders as individual covariates (Additional file 1: Tables S1, S2). We added the group effect for those with sufficient observations. In addition, we evaluated field size, bare soil and stubble coverage, as well as crop stage as individual covariates affecting occupancy in field interiors. For borders, we added the effects of the number of native trees (highly correlated with border width, total trees, and shrub coverage), and dead vegetation cover for omnivore or granivore groups that could relate to seed availability.

We standardized explanatory variables to ensure that the numerical optimization algorithm finds the correct parameter estimates (Cooch and White 2013), and discarded correlated ones $(r>0.4)$ leaving one of each pair of variables. We made inferences regarding the strength of the effect of covariates by examining $95 \%$ confidence intervals $(\mathrm{CI})$, whereby if zero occurred within the $\mathrm{CI}$ the effect of the covariate was considered weak. We evaluated relative plausibility of candidate models following an information theoretic approach using Akaike's Information Criterion corrected for small samples and overdispersion (QAICc) based on the $c$-hat $(\widehat{c})$ variance inflation factor. The latter is a measure of overdispersion used to adjust for lack of fit, and is calculated as the saturated model deviance over the bootstrapped deviance after 1000 simulations (Cooch and White 2013) and performed model averaging over real parameter values (Burnham and Anderson 2002).

We analyzed pooled arthropod counts fitting generalized linear mixed models (GLMM) using lme4 package in program $\mathrm{R}$ ( $\mathrm{R}$ Core Team 2013; Bates et al. 2015). We assumed a Poisson distribution for counts, and considered a possible effect of seasons, nested as repeated measures in borders, and the latter nested in fields. We included standardized covariates of grass height, dead vegetation and shrub coverage, number of native trees, insecticide applications in borders, and grass or bare soil coverage, soybean phenological stage, and insecticide applications in the center of the fields. We considered insecticides applications as a binomial variable since each farmer applied different products and concentrations, which made it difficult to carry out a comparison. Because arthropods counts were overdispersed, we added an observation-level normally distributed random effect, equivalent to a log-normal Poisson model (Elston et al. 2001), to avoid underestimation of standard errors. For example, the number of arthropods $n_{i j k}$ counted on border $i$ of field $j$ at season $k$ followed a Poisson distribution $n_{i j k} \sim$ Poisson $\left(\mu_{i j k}\right)$, then the model was specified as follows:

$$
\log \left(\mu_{i j k}\right)=\alpha_{k}+\beta x_{i j k}+\varepsilon_{j}+\varepsilon_{i j}+\varepsilon_{i j k},
$$

where $\alpha_{k}$ is a categorical fixed effect of the seasons, a continuous $\beta$ fixed effects of a covariate $x_{i j k}$ (e.g. grasses height), and random effects of the field $\varepsilon_{j}$, border $\varepsilon_{i j}$, and 
observation $\varepsilon_{i j k}$ with Normal distributions. We then compared models with and without the "field" random effect and different covariates, and selected the best model using AIC corrected for small samples (AICc) (Burnham and Anderson 2002).

\section{Results}

We sampled 20 fields and 78 field borders, and recorded 82 species of birds representing 27 families. We estimated occurrence of 52 species from 18 families, i.e., those that either individually or when pooled with species of the same guild had a sufficient number of observations (e.g. in borders 17 subgroups, with nine species estimated individually; Table 1). We detected fewer species in field interiors than in borders, with only 13 species having a sufficient number of detections to estimate occurrence, consisting of ground omnivores, Columbiformes, ground nesting granivores, and aerial foragers (Table 1$)$.

Field sizes averaged 35 ha (range $=17-140$ ha; $\mathrm{SD}=29)$ and borders were $4.02 \mathrm{~m}$ wide on average (range $=1-16 \mathrm{~m} ; \mathrm{SD}=3.14$ ). Other field and border characteristics and weather covariates in Additional file 1: Tables S3, S4, S5. Planting dates ranged from 31 October to 25 November for most fields. However, during the second year of our study, two crops were planted later in the season (3 December and 2 January) because of drought and four fields were not sown. We discarded two fields from the analysis because of the presence of cattle. Most insecticide applications started during the second phenological stage of soybeans $(\mathrm{V})$, and continued, before both the $\mathrm{R}$ stages (third and fourth season; Additional file 2: Fig. S1).

\section{Bird occurrence}

Avian detection and occurrence estimates in the interior of the fields were highly variable, probably due to the low detection of species, and we were unable to establish a clear relationship with the covariates in most cases (Additional file 1: Table S6; Additional file 2: Fig. S2). Detection probabilities varied from a minimum of $<20 \%$ to a maximum of $80 \%$ (Additional file 2: Fig. S2a). Detection increased with increasing temperatures for ground omnivores in the first season ( $\widehat{\beta}=0.79 ; 95 \%$ CI $0.21,1.36)$, and for aerial foragers in the third season $(\widehat{\beta}=2.11$; $95 \%$ CI $0.51,3.70)$. The best model explaining occupancy of groups using the interior of the fields was usually the null model (20-60\% of support), whereas models incorporating covariates demonstrated weak effects. Ground omnivores such as Upland Sandpiper (Bartramia longicauda), Spotted Nothura (Nothura maculosa), and Southern Lapwing (Vanellus chilensis) were observed in the center during the pre-sowing season and during the soybean $\mathrm{V}$ stage, where vegetative height averaged $15 \pm 7 \mathrm{~cm}$. On the other hand, Columbiformes used fields only before planting of soybean. The only groups detected throughout the soybean cycle in the interior of the fields were ground granivore foliage gleaners, and Spotted Nothuras. Aerial foragers used the interior of the fields most often when soybeans were in the $\mathrm{V}$ and $\mathrm{R}$ stages (Additional file 2: Fig. S2b).

The total number of trees affected detection probabilities in field borders for most groups, except ground granivore gleaners and aerial foragers (Additional file 1: Table S7). This effect was positive for all groups, except for ground omnivores and Chalk-browed Mockingbird (Mimus saturninus). Overall, detection probabilities at field borders were highest $(\hat{p}>0.5)$ for Picui Ground Dove (Columbina picui) and increased with the number of trees. Similarly, Grassland (Ammodramus humeralis) and Rufous-collared (Zonotrichia capensis) Sparrows had high detection probabilities, but remained constant. Ground omnivores had the lowest detection rates $(\hat{p}<0.2)$, with rates decreasing slightly with the number of native trees.

Best-selected models suggest that the number of native trees positively influenced the occurrence of most species in field borders, with the exception of ground omnivores, which were unaffected by any variable (Additional file 1: Table S7). Overall, sparrows exhibited the greatest occurrence probabilities. The effect of native trees was strong for most groups, with most insectivore species reaching $100 \%$ occurrence with more than 11 native trees $\left(\widehat{\beta}_{\text {tree }}=7.89 ; 95 \%\right.$ CI 2.07, 13.72; Fig. 2d $)$. Granivores such as Picui Ground Dove $\left(\widehat{\beta}_{\text {tree }}=2.95\right.$; $95 \%$ CI $0.86,5.04$; Fig. 2a) and granivore foliage gleaners $\left(\widehat{\beta}_{\text {tree }}=4.05 ; 95 \%\right.$ CI 1.60, 6.50; Fig. 2b), reached $100 \%$ occurrence with more than 15 trees. Then, 18 native trees for Goldenbilled Saltator $\left(\widehat{\beta}_{\text {tree }}=4.05\right.$; $95 \%$ CI 1.60, 6.50; Fig. $\left.2 \mathrm{~b}\right)$, and Columbiformes with more than 28 native trees $\left(\widehat{\beta}_{\text {tree }}=2.95 ; 95 \%\right.$ CI 0.86, 5.04; Fig. 2a) were necessary for these species to reach the highest occupancy.

Granivore foliage gleaners, in addition to native trees, also were positively affected by grass height, reaching $80 \%$ occurrence where grass height was $>60 \mathrm{~cm}(\widehat{\beta}=0.80$; $95 \%$ CI 0.08 , 1.51; Fig. 3). The best models explaining occurrence of salliers and aerial foragers included weak effects of distance to forest patches and native trees $\left(\widehat{\beta}_{\text {forest }}=0.52 ; 95 \%\right.$ CI $0.00,1.04$ and $\widehat{\beta}_{\text {tree }}=7.80 ; 95 \%$ CI -1.26 , 16.87; Fig. 2e). Finally, the number of native trees exhibited a weak effect on ground nesting granivore gleaners as well $\left(\widehat{\beta}_{\text {tree }}=-0.41 ; 95 \% \mathrm{CI}-0.97,0.15\right.$; Fig. 2c).

\section{Arthropods}

In field interiors, arthropods counts collected with sweep net were likely biased in the first season because of the 

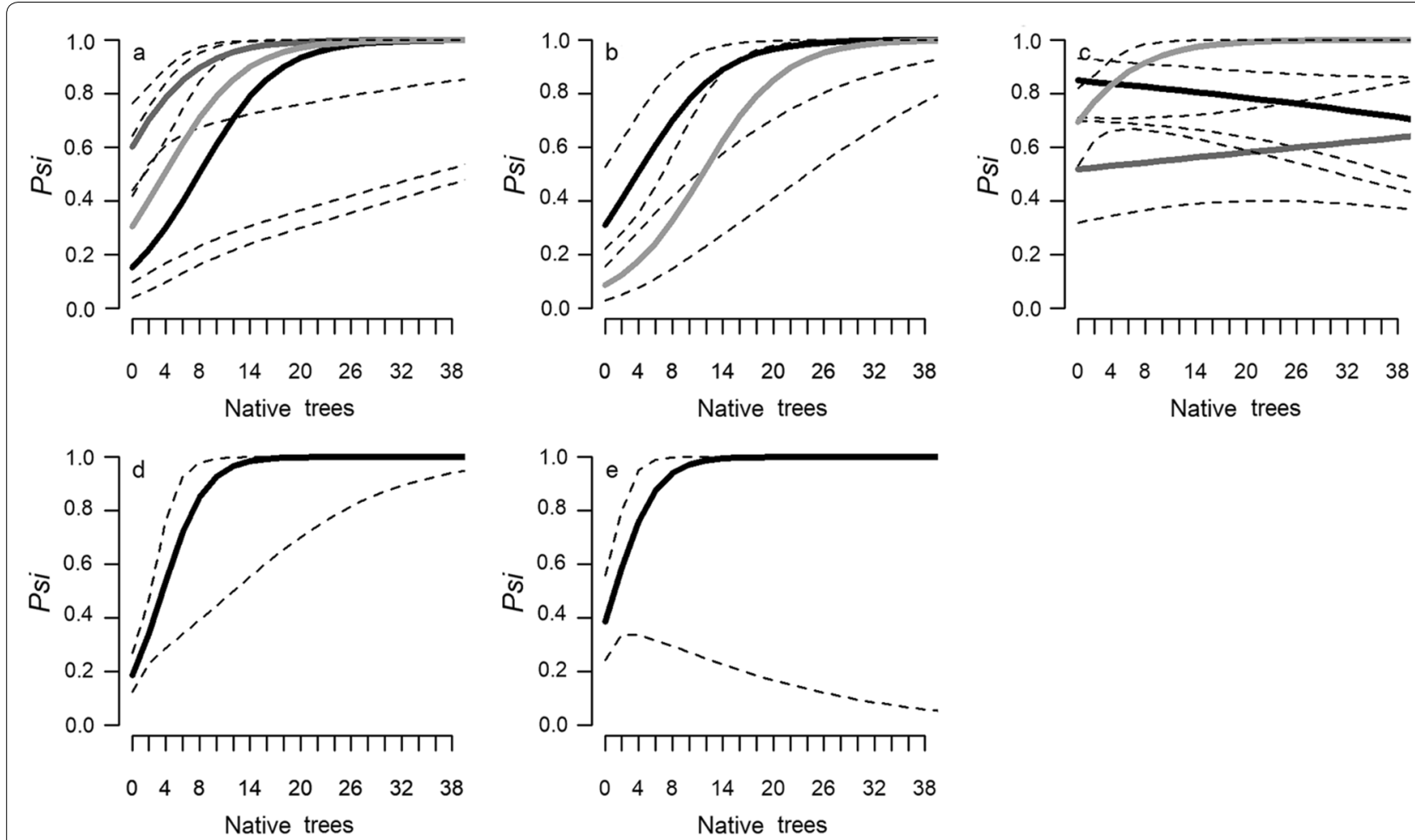

Fig. 2 Occupancy $(\widehat{P S i} \pm 95 \% \mathrm{Cl}$ ) probabilities for birds in relation to the number of native trees at borders of soybean fields in Paraná department, Entre Ríos, Argentina, 2007-2009. a Columbiformes (black), Picui Ground Dove (grey), Eared Dove (light grey); b granivore foliage gleaners (black), Golden-billed Saltator (grey); c Grassland Sparrow (black), ground nesters passerine granivores (grey), Rufous-collared Sparrow (light grey); d insectivores; e aerial foragers and salliers. Details of species in Table 1

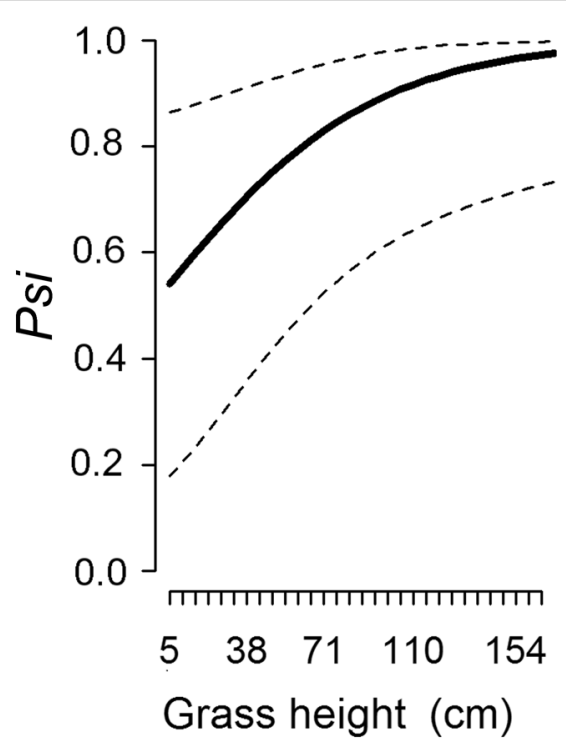

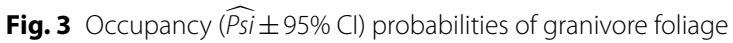
gleaners by grass height at borders of soybean fields in Paraná department, Entre Ríos, Argentina, 2007-2009. Details of species in Table 1 difficulty of sampling with this method with no vegetation and thus was lower during the pre-sowing stage, but increased in the following seasons and rapidly with grass cover $(\widehat{\beta}=0.66$; 95\% CI 0.38, 0.94; Fig. 4; Additional file 1: Table S8). Conversely, availability of arthropods based on vacuum samples exhibited a weak effect of bare soil $(\widehat{\beta}=-0.11,95 \% \mathrm{CI}-0.25,0.03)$ and no differences among crop stages. The main taxa collected with vacuum were Hymenoptera and Hemiptera, followed by Coleoptera, and Diptera in the first season. On the other hand, all groups were collected with sweep net (except the first season). Overall, invertebrates available for birds were maximized during the third season, followed by the second. Hemiptera was the most represented order, which maximized in the second crop stage, followed by Hymenoptera and Coleoptera, and then by Diptera and Araneae (Additional file 2: Fig. S3).

Similar to field interior, in borders, the main taxa collected with vacuum were Hymenoptera, Coleoptera and Hemiptera, but other groups were also represented; and all groups were collected with sweep net. The overall count of arthropods was always greater when collected with sweep net during all crop stages. Arthropod counts 


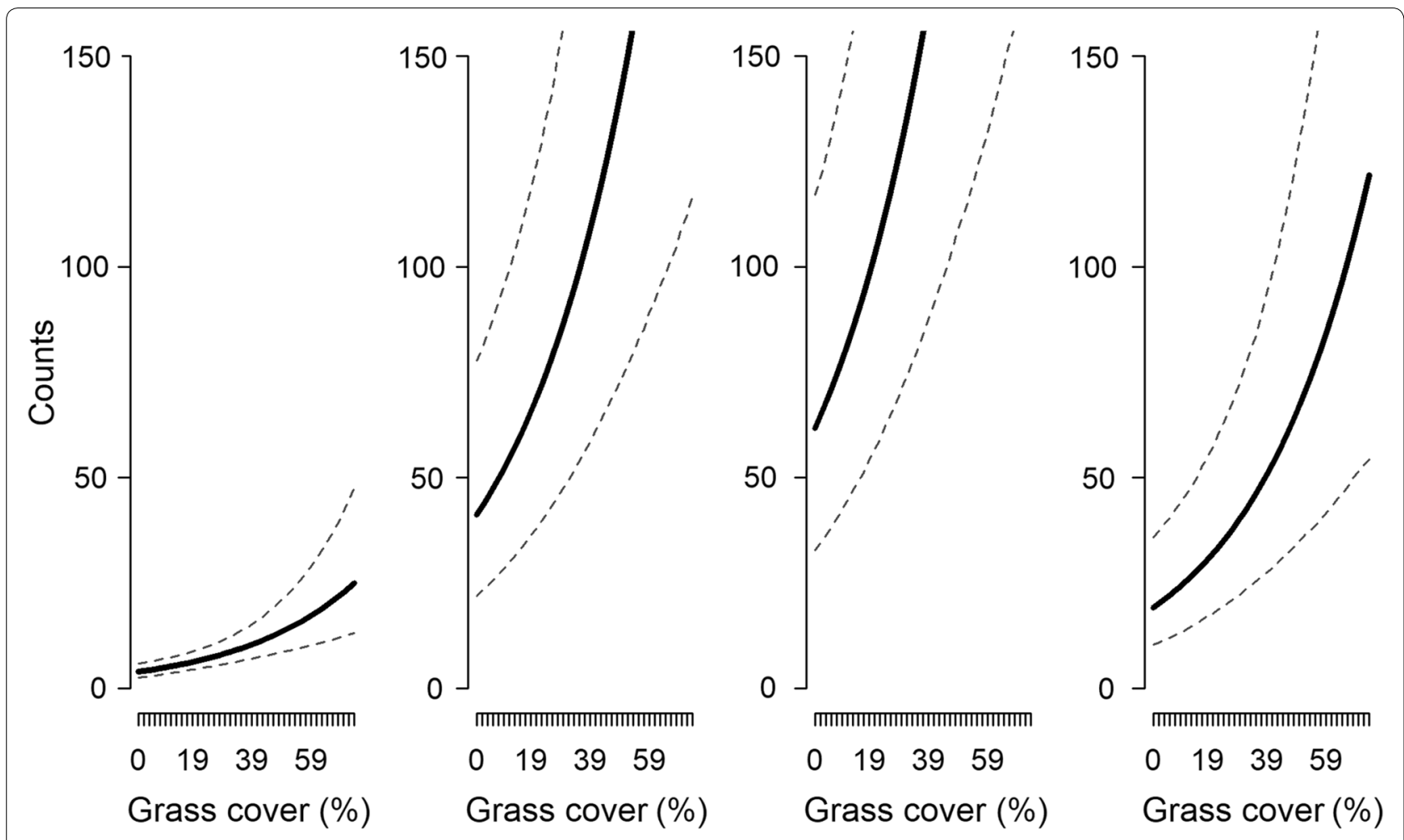

Fig. 4 Counts $\pm 95 \% \mathrm{Cl}$ of main arthropod orders assumed to be consumed by birds at the interior of soybean fields, in Paraná department, Entre Ríos, Argentina, 2007-2009. Seasons 1 to 4 (left to right)

in borders were greater during the last three crop stages than during the pre-sowing period, independent of collection method, and evidenced effects in time when analyzed separately. There was a weak positive effect of grass height $(\widehat{\beta}=0.13 ; 95 \% \mathrm{CI}-0.02,0.28)$ on arthropods collected with sweep net, and a strong negative effect when collected with vacuum $(\widehat{\beta}=-0.23 ; 95 \% \mathrm{CI}-0.36$, -0.09 ; Fig. 5; Additional file 1: Table S8). Coverage of dead vegetation had a strong negative effect on arthropod counts collected by sweep net $(\widehat{\beta}=-0.40 ; 95 \% \mathrm{CI}-0.65$, -0.14 ; Fig. 6), but on invertebrates collected with vacuum the effect was weak ( $\widehat{\beta}=0.25 ; 95 \% \mathrm{CI}-0.04,0.54)$. The effects of insecticides $(\widehat{\beta}=0.32 ; 95 \% \mathrm{CI}-0.05,0.69)$ and native trees $(\widehat{\beta}=-0.18 ; 95 \%$ CI $-0.36,-0.003)$ were weak as well for those collected with vacuum. Total counts for Hymenoptera were always high, together with Hemiptera which dropped in the last season, and the lowest for Lepidoptera and Orthoptera (Additional file 2: Fig. S4).

\section{Discussion}

We found that the highest occupancy for most guilds of insectivorous birds occurred in soybean field borders containing at least 10 native trees. Borders also hosted a high number of arthropods, including agriculturally beneficial species suggesting little effect from insecticide applications to crops. These results suggest a small number of native trees in borders, coupled with a complex vegetation structure with grasses and shrubs, can support a wide spectrum of edge-associated insectivorous birds. Birds considered problematic for agriculture, such as pigeons, had highest occupancy in borders with very high native tree density, suggesting that a low density of native trees is beneficial to a wide-range of species but not to species considered to be agricultural pests. Concurrently, ground omnivores, ground-nesting granivores, and insectivorous aerial foragers showed no relationship with field borders but did utilize soybean fields suggesting that bird species can adapt to some level of agricultural intensification despite insecticide applications, including insectivore species.

We recorded 82 bird species in soybean fields and borders, representing $\sim 45 \%$ of the species of landbirds potentially found in our study area in Entre Ríos (De la Peña 2006; Narosky and Yzurieta 2010; Dardanelli, pers. comm.), the most common of which are usually associated with agricultural and human-dominated environments (Goijman and Zaccagnini 2008; Solari and Zaccagnini 2009; Di Giacomo and de Casenave 2010; Goijman et al. 2015). Our results support the prediction 


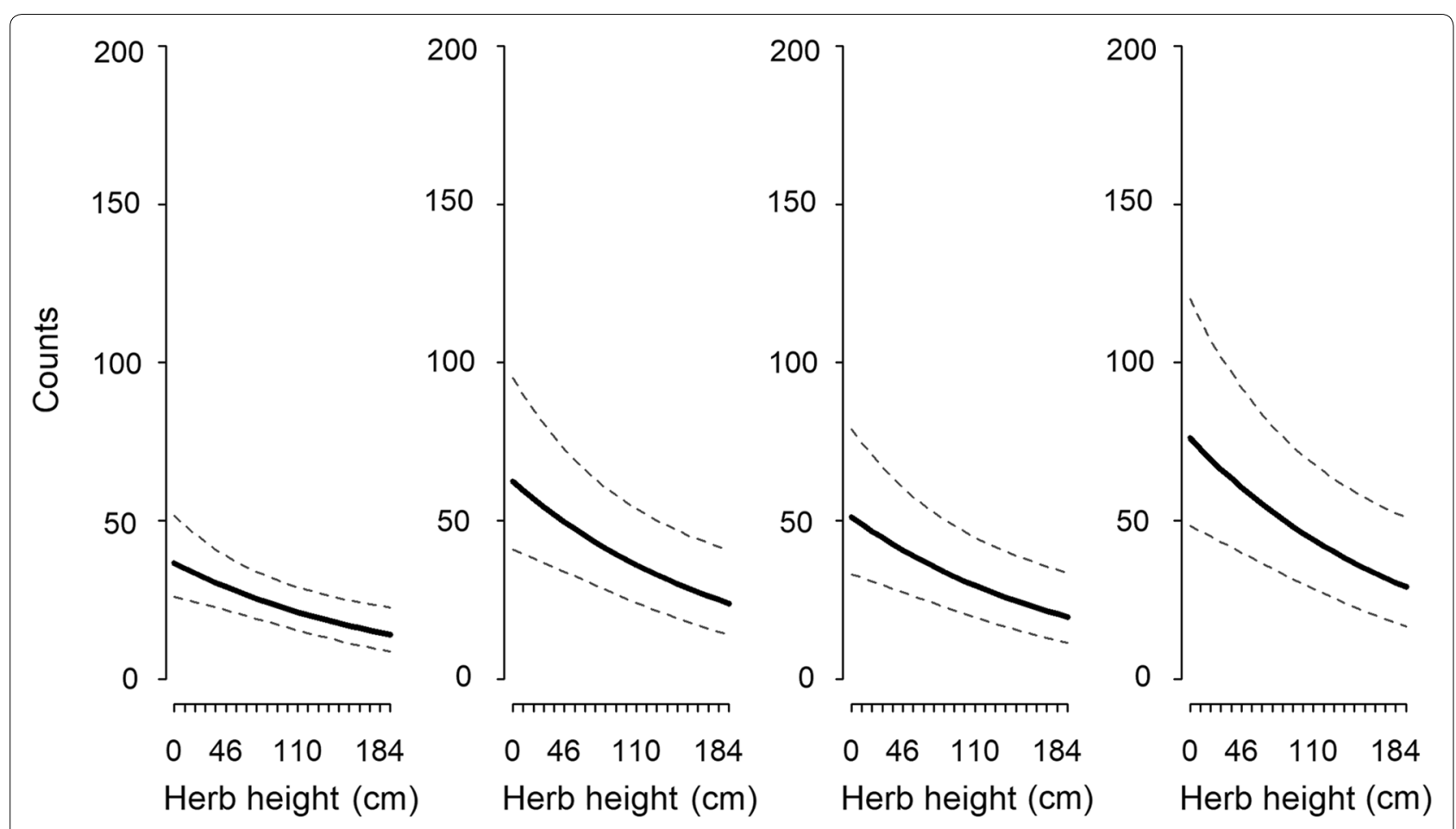

Fig. 5 Counts $\pm 95 \% \mathrm{Cl}$ of main arthropod orders collected with vacuum assumed to be consumed by birds by height of herbaceous vegetation at the borders of soybean fields, at seasons 1 to 4 (left to right), in Paraná department, Entre Ríos, Argentina, 2007-2009

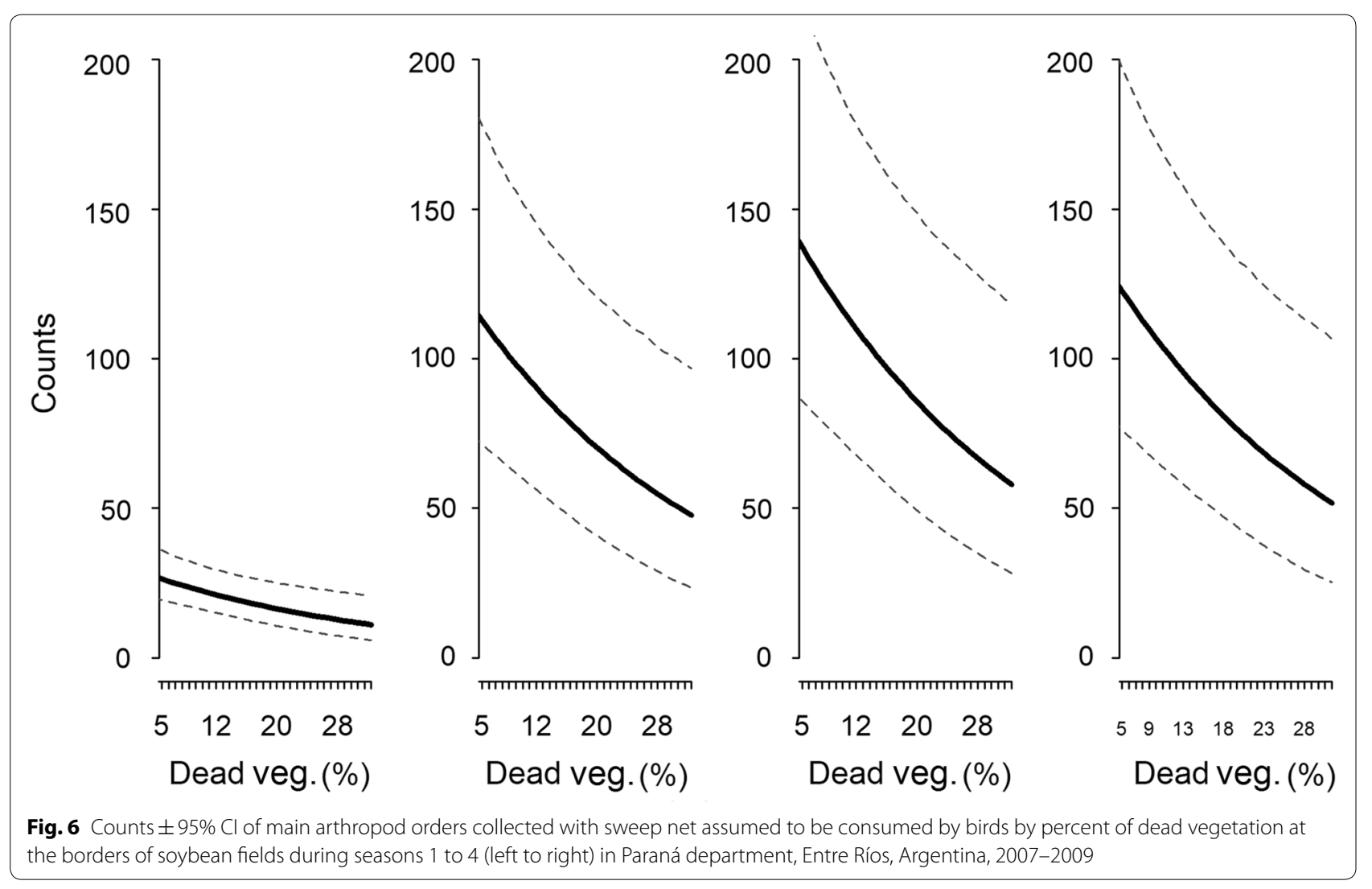


that borders with complex vegetation structure maintain more bird species, and highlight the importance of maintaining heterogeneity in the agricultural matrix (Jobin et al. 2001; Benton et al. 2003; Goijman and Zaccagnini 2008; Di Giacomo and de Casenave 2010).

Foraging guilds benefiting from the presence of vegetated field borders consisted of foliage gleaners, ground and foliage omnivores, and ground insectivores, and for the most part, vegetation structure was key to determining their occurrence, despite insecticide applications. In addition to favoring insectivores, vegetated borders also favored granivorous foliage gleaners, which had highest occupancy where vegetative complexity was highest ( $>15$ native trees and grasses height $>60 \mathrm{~cm}$ ). Many species of small passerines responded to vegetation structure and/or land cover at a finer than landscape scales, even in intensified agroecosystems (Robinson et al. 2001; Goijman et al. 2015). Because herbaceous strata, which affected granivorous foliage gleaners, showed some changes in borders during the crop cycle, there is the potential that the assumption of population closure was partially violated for this guild, which should be considered in the interpretation of our results (MacKenzie et al. 2017). Although it was possible that some species of granivorous foliage gleaners may have been absent at times, this does not change our interpretation that they benefit from a more complex vegetation structure.

As predicted, we did not find an association of aerial insectivores (i.e., salliers and aerial foragers) with field borders. These groups were not dependent on vegetation structure in borders because they are more mobile and respond to larger-scale landscape-level factors and were more associated with open habitats (Gavier-Pizarro et al. 2012; Goijman et al. 2015; Calamari et al. 2016). Other groups associated with open habitats that showed no relationship with field borders were ground omnivores and ground-nesting granivores, the latter associated positively with row crops (Codesido et al. 2008; Goijman et al. 2015).

We did not have sufficient data to examine our prediction that avian occurrence in soybean fields and borders directly corresponds to prey availability. Counts of arthropods assumed to be preyed upon by birds were the highest in the second and third crop stages, even after insecticide applications in fields and borders, lowest during the pre-sowing season, and decreased during the last crop stage in field interiors, especially Hemipteran likely because of insecticide applications. Low arthropod abundance in the first crop stage could be related to the absence of standing vegetation, and seasonality intrinsic to invertebrate populations, especially in temperate areas (Wolda 1988). Additionally, the low observed abundance could be due to sampling bias from sweep net sampling due to the lack of vegetation early in the season. Borders hosted a greater number of arthropods than field interiors, which was expected as vegetated borders serve as refugees (Weyland and Zaccagnini 2008; Varni 2010). The high dispersal capacity of several species of arthropods and the observed lag between times of applications in different fields helps maintain total abundance in vegetated borders and facilitate dispersion into fields (Duelli et al. 1990; Lee et al. 2001). Moreover, borders hosted predominantly Hymenopteran, beneficial invertebrates which seemed to be unaffected by insecticides, although Araneae, which are also beneficial were common as well. Hemipteran and Coleopteran which could be pests or beneficial, were also common (Beltramo et al. 2006; Avalos et al. 2016).

Most birds in the study area belonging to the different foraging guilds have an exclusively or partly insectivorous diet. This implies that the complex vegetation structure of field borders, associated with increased use of ground and foliage insectivores and gleaners, might contribute to an invertebrate pest control service (Kirk et al. 1996; Whelan et al. 2008, 2016; Kross et al. 2016). Granivore gleaners also had high occurrence and, in addition to their role as seed predators, could be important consumers of pest arthropods, especially in the breeding season when they consume invertebrates to feed their chicks (Whelan et al. 2008). The diversity of foraging guilds with different behaviors, and the diversity of species preying on different invertebrates could contribute to a broad spectrum of pest control (Philpott et al. 2009). However, they could also negatively affect beneficial invertebrates, such as Hymenopteran, by preying upon them (Grass et al. 2017).

Borders with native trees not only benefited many insectivore avian guilds, but also increased the occurrence of agricultural pest species (pigeons and Eared Dove (Zenaida auriculata); Calamari et al. 2018a). However, these species' occurrence was maximized with almost twice the number of native trees compared to the other guilds, similar to the observed preference of Eared Dove, Spot-winged and Picazuro pigeons (Patagioenas maculosa and P. picazuro) for landscapes where crops are interspersed with native and exotic woodlots (Bucher 1990; Gavier-Pizarro et al. 2012; Goijman et al. 2015; Zufiaurre et al. 2017; Calamari et al. 2018a).

Many species used soybean field interiors, demonstrating how some species can adapt to some agricultural intensification (Gavier-Pizarro et al. 2012; Goijman et al. 2015). Also, some species, including ground-nesting species such as Grassland Yellow Finch (Sicalis luteola), Rufous-collared and Grassland Sparrows, and Spotted Nothuras were present throughout the soybean growing cycle. However, we could not relate field use by birds 
to covariates, which could be due to the low frequency of species using fields, and points to the need for larger sample sizes in future research.

During the pre-sowing stage and when soybean plants were developing, we detected Upland Sandpipers, a nonbreeding migrant from North America (BirdLife International 2013), and Southern Lapwings. Taller soybean plants negatively affected both species, collaborating previous studies in soybean crops (Goijman et al. 2015). The presence of these insectivorous species in earlier crop stages suggests that habitat use is not limited by local food availability, and that individuals may still be able to find food in crop fields (Champlin et al. 2009). Other insectivores such as the aerial forager Brown-chested Martin (Progne tapera) and the sallier Fork-tailed Flycatcher (Tyrannus savana), used later crop stages, when aerial invertebrate abundance was greatest, which implies that their foraging coincides with periods of pest emergence, and that they can be providing a valuable ecosystem service (Kirk et al. 1996; Saluso et al. 2007; Philpott et al. 2009).

Species using field crops, especially during latter crop stages, could be vulnerable to pesticides although there is a need for further work to establish the actual direct risks (Boutin et al. 1999; Goldstein et al. 1999; Mineau 2002). Some insecticides used in the area such as cypermethrin, have low toxicities, but we found in cases where endosulfan was used, which is highly toxic to birds, could be of particular concern (Mineau 2002; Bernardos et al. 2007).

Future research is needed to quantify the pest control service provided by birds and evaluate the benefits that farmers could obtain from conserving insectivore birds, maybe from exclusion experiments and crop damage measurements. In addition, consistent with other research in the region (Weyland and Zaccagnini 2008; Varni 2010), we did not find strong evidence of an effect of insecticides on invertebrate pooled counts in field borders. However, additional studies are necessary to account for the temporal effects of insecticides, evaluating invertebrate orders individually, and the effects of chemical types, application intensity, and concentrations to better understand the mechanisms driving our finding.

\section{Conclusions}

The original vegetation in the area consists of Espinal forest, dominated by xerophytic woody species, thus we expected benefits of native trees on most species (Goijman and Zaccagnini 2008; Di Giacomo and de Casenave 2010). With 10 to 15 native tree species in borders, coupled with a complex vegetation structure with shrubs and grasses, we could conserve a wide spectrum of insectivorous birds, which is consistent with other studies that recommend planting or conserving tress in borders (Kross et al. 2016). Despite the benefits derived from complex vegetation structure, increasing tree density by more than 20 per border may attract pigeons and Eared Doves that are considered problematic for agriculture (Calamari et al. 2018a).

The resulting small reduction in soybean yield, because of vegetated borders, may be an acceptable trade-off if it results in increased pest control services provided by the avian community and predatory invertebrates (Lee et al. 2001; Stamps et al. 2008). Consequently, there is an important need to evaluate the real economic benefits in addition to their intrinsic conservation value.

Vegetated field borders function as a refuge for arthropods, especially agriculturally beneficial taxa such as Hymenopterans, indicating a need to minimize pesticide drift into borders. Furthermore, several groups of birds use the interior of the fields and potentially provide pest control, however, they may be vulnerable to pesticides which points to a critical need for the conscientious use of these products. More research is needed comparing crops with and without applications to define more clearly the mechanisms operating at the field level, which affect avian and arthropod communities towards providing better management of croplands for the conservation of these species and the services they provide.

\section{Supplementary information}

Supplementary information accompanies this paper at https://doi. org/10.1186/s40657-020-00235-4.

Additional file 1: Table S1. A priori avian occupancy and detection models in the interior of soybean fields. Table S2. A priori avian occupancy and detection models in borders of soybean fields. Table S3. Descriptive statistics of covariates used to model bird occupancy in the interior of fields. Table S4. Descriptive statistics of covariates used to model bird occupancy in borders of fields. Table S5. Descriptive statistics of main weather covariates during bird surveys in Entre Ríos. Table S6. Best models predicting avian occupancy and detection in the interior of soybean fields. Table S7. Best models predicting avian occupancy and detection in borders of soybean fields. Table S8. Poisson generalized linear mixed models predicting abundance of main arthropod orders consumed by birds.

Additional file 2: Figure S1. Sampling scheme in soybean fields and borders showing survey dates and insecticide applications over time. Figure S2. Detection and occupancy probabilities for bird groups in the interior of fields at different seasons. Figure S3. Total arthropod counts collected with vacuum, sweep net, and pooled in the interior of soybean fields.

Figure S4. Total arthropod counts collected with vacuum, sweep net, and pooled in borders of soybean fields.

\section{Acknowledgements}

We thank Belén Poliserpi, Jimena Damonte, José Segovia, Alejandro Znidar, and Matías Morales, who participated in the field surveys. Finally, we thank Nicole Lazar, Jeffrey Hepinstall-Cymerman, Robert Cooper, and John Carroll for their thoughtful and helpful comments. Finally, we thank the handling editor, and two anonymous reviewers for very helpful and constructive comments. 


\section{Authors' contributions}

APG and MEZ conceived the idea and design; MJC supervised research; APG and VDV collected data; APG wrote the paper; APG, MJC, JJT, VDV and MEZ edited/commented on drafts; APG, VDV and JJT developed or designed methods; and APG analyzed the data. All authors read and approved the final manuscript.

\section{Funding}

Research was funded by National Institute of Agricultural Technology (INTA) Projects (2009-2012) AERN 292241, AERN 292221.

\section{Availability of data and materials}

The datasets generated and/or analysed during the current study are available from the corresponding author upon reasonable request.

\section{Ethics approval and consent to participate}

Not applicable.

\section{Consent for publication}

Not applicable.

\section{Competing interests}

The authors declare that they have no competing interests.

\section{Author details}

${ }^{1}$ Instituto de Recursos Biológicos, CIRN, Instituto Nacional de Tecnología Agropecuaria (CNIA-INTA), Hurlingham, Buenos Aires, Argentina. ${ }^{2}$ D.B. Warnell School of Forestry and Natural Resources, University of Georgia, Athens, GA 30602, USA. ${ }^{3}$ Present Address: Athens, GA, USA. ${ }^{4}$ Present Address: Laboratorio de Genómica Ecológica y Evolutiva, Irapuato, Gto, México. ${ }^{5}$ Present Address: Guyra Paraguay-CONACYT, Av. Cnel. Carlos Bóveda, Parque Ecológico Capital-Viñas Cué, Asunción, Paraguay. ${ }^{6}$ Present Address: Instituto Saite, Asunción, Paraguay. ${ }^{7}$ Present Address: The Ronin Institute, Montclair, NJ, USA. ${ }^{8}$ Present Address: Instituto Nacional de Tecnología Agropecuaria (INTA), CABA, Argentina.

Received: 17 April 2020 Accepted: 9 November 2020

Published online: 07 December 2020

\section{References}

Alessio VG, Beltzer AH, Lajmanovich RC, Quiroga M. Ecología alimentaria de algunas especies de Passeriformes (Furnariidae, Tyrannidae, Icteridae y Emberizidae): Consideraciones sobre algunos aspectos del nicho ecológico. In: Aceñolaza FG, editor. Temas de la biodiversidad del Litoral Fluvial Argentino II. Tucumán: Ediciones Magna; 2005. p. 441-82.

Avalos DS, Mangeaud A, Valladares GR. Parasitism and food web structure in defoliating Lepidoptera_parasitoid communities on soybean. Neotrop Entomol. 2016:45:712-7.

Azpiroz AB. Aves del Uruguay: Lista e introducción a su biología y conservación. Montevideo: Aves Uruguay-GUPECA; 2001

Bates DM, Maechler M, Bolker M, Walker S. Fitting linear mixed-effects models using Ime4. J Stat Softw. 2015;67:1-48.

Beltramo J, Bertolaccini I, González A. Spiders of soybean crops in Santa Fe province, Argentina: influence of surrounding spontaneous vegetation on lot colonization. Braz J Biol. 2006:66:891-8.

Beltzer AH. Aspectos tróficos de la comunidad de aves de los esteros del Iberá. In: Alvarez BB, editor. Fauna del Iberá. Chaco-Corrientes: Universidad Nacional del Nordeste; 2003. p. 257-71.

Benton TG, Vickery JA, Wilson JD. Farmland biodiversity: is habitat heterogeneity the key? Trends Ecol Evol. 2003;18:182-8.

Bernardos JN, Zaccagnini ME, Mineau P, Decarre J, De Carli R. Calculadora de riesgo ecotoxicológico para aves: Sistema soporte de decisiones para el control de plagas con criterios ambientales 3.0. Buenos Aires: INTA; 2007

Bibby CJ, Burgess ND, Hill DA, Mustoe SH. Bird census techniques. London: Academic Press; 2000

BirdLife International. IUCN Red List for birds. 2013. https://www.birdlife.org. Accessed 30 Aug 2013.

Bortoluzzi A, Aceñolaza P, Aceñolaza F. Caracterización ambiental de la cuenca del arroyo las conchas, provincia de Entre Ríos. In: Aceñolaza FG, editor.
Temas de la biodiversidad del litoral fluvial Argentino III. Serie Miscelanea 17. Tucumán: Instituto Superior de Correlacion Geologica; 2008. p. 219-30.

Boutin C, Freemark KE, Kirk DA. Farmland birds in southern Ontario: field use, activity patterns and vulnerability to pesticide use. Agric Ecosyst Environ. 1999;72:239-54.

Boutin C, Jobin B. Intensity of agricultural practices and effects on adjacent habitats. Ecol Appl. 1998;8:544-57.

Bucher $\mathrm{EH}$. The influence of changes in regional land-use patterns on Zenaida Dove populations. In: Pinowsky J, Summers-Smith JD, editors. Granivorous birds in agricultural landscapes. Warsaw: Polish Academy of Sciences; 1990. p. 291-303.

Burkart R, Bárbaro NO, Sánchez RO, Gómez DA. Eco-regiones de la Argentina. Buenos Aires: Secretaría de Recursos Naturales y Desarrollo Sustentable, Administracion de Parques Nacionales; 1999.

Burnham KP, Anderson DR. Model selection and multimodel inference: a practical information-theoretic approach. 2nd edn. New York: Springer; 2002.

Cabrera A. Fitogeografía de la República Argentina. Bol Soc Argent Bot. 1971;14:1-43.

Calamari NC, Cerezo Blandón A, Canavelli SB, Dardanelli S, Gavier-Pizarro Gl, Zaccagnini ME. Long-term association of Tyrannus savana and Sturnella superciliaris density with land cover and climatic variables in agroecosystems of Argentina. El Hornero. 2016;31:97-112.

Calamari NC, Canavelli SB, Cerezo A, Dardanelli S, Bernardos JN, Zaccagnini ME. Variations in pest bird density in Argentinean agroecosystems in relation to land use and/or cover, vegetation productivity and climate. Wildlife Res. 2018;45:668-78.

Calamari NC, Vilella FJ, Sica YV, Mercuri PA. Patch and landscape responses of bird abundance to fragmentation in agroecosystems of east-central Argentina. Avian Conserv Ecol. 2018;13:3.

Capinera J. Insects and wildlife: arthropods and their relationships with wild vertebrate animals. Hoboken: Wiley-Blackwell; 2010.

Champlin TB, Kilgo JC, Moorman CE. Food abundance does not determine bird use of early-successional habitat. Ecology. 2009;90:1586-94.

Codesido M, Fischer CG, Bilenca D. Land use patterns and bird assemblages in agroecosystems of the Pampean Region, Argentina. Ornitol Neotrop. 2008;19:575-85.

Cooch EG, White GC. Program MARK: a gentle introduction, 12th edn. Colorado State University. 2013. https://www.phidot.org/software/mark/docs/ book/. Accessed 17 Feb 2013.

De la Peña MR. Reproducción de las aves Argentinas, con descripción de pichones. Buenos Aires: Monografía LOLA; 2005.

De la Peña MR. Lista distribución aves Santa Fe Entre Ríos. Buenos Aires: Monografía LOLA; 2006.

Di Giacomo AS, de Casenave UL. Use and importance of crop and field-margin habitats for birds in a neotropical agricultural ecosystem. Condor. 2010;112:283-93.

Donald PF, Sanderson FJ, Burfield IJ, Van Bommel FPJ. Further evidence of continent-wide impacts of agricultural intensification on European farmland birds, 1990-2000. Agric Ecosyst Environ. 2006;116:189-96.

Douglas DJT, Vickery JA, Benton TG. Improving the value of field margins as foraging habitat for farmland birds. J Appl Ecol. 2009;46:353-62.

Duelli P, Studer M, Marchand I, Jakob S. Population movements of arthropods between natural and cultivated areas. Biol Conserv. 1990;54:193-207.

Elston DA, Moss R, Boulinier T, Arrowsmith C, Lambin X. Analysis of aggregation, a worked example: numbers of ticks on Red Grouse chicks. Parasitology. 2001;122:563-9.

FAOSTAT. Commodities by country 2011: soybeans. 2013. https://faostat.fao. org. Accessed 18 June 2013

Foley JA, Ramankutty N, Brauman KA, Cassidy ES, Gerber JS, Johnston M, et al. Solutions for a cultivated planet. Nature. 2011;478:337-42.

Freemark K, Boutin C. Impacts of agricultural herbicide use on terrestrial wildlife in temperate landscapes: a review with special reference to North America. Agric Ecosyst Environ. 1995;52:67-91.

Gavier-Pizarro GI, Calamari NC, Thompson JJ, Canavelli SB, Solari LM, Decarre J, et al. Expansion and intensification of row crop agriculture in the Pampas and Espinal of Argentina can reduce ecosystem service provision by changing avian density. Agric Ecosyst Environ. 2012;154:44-55.

Goijman AP, Conroy MJ, Bernardos JN, Zaccagnini ME. Multi-season regional analysis of multi-species occupancy: implications for bird conservation in agricultural lands in east-central Argentina. PLOS ONE. 2015;10:e0130874. 
Goijman AP, Zaccagnini ME. The effects of habitat heterogeneity on avian density and richness in soybean fields in Entre Ríos, Argentina. Hornero. 2008;23:67-76

Goldstein MI, Lacher TE, Woodbridge B, Bechard MJ, Canavelli SB, Zaccagnini ME, et al. Monocrotophos-induced mass mortality of Swainson's Hawks in Argentina, 1995-96. Ecotoxicology. 1999:8:201-14.

Grass I, Lehmann K, Thies C, Tscharntke T. Insectivorous birds disrupt biological control of cereal aphids. Ecology. 2017;98:1583-90.

Hill RW. Fisiología comparada comparada: un enfoque ambiental. Barcelona: Reverté; 1980

Jobin $B$, Choiniere L, Belanger L. Bird use of three types of field margins in relation to intensive agriculture in Quebec, Canada. Agric Ecosyst Environ. 2001:84:131-43.

Kirk DA, Eveden MD, Mineau P. Past and current attempts to evaluate the role of birds as predators of insect pests in temperate agriculture. In: Nolan $\mathrm{V}$ Ketterson ED, editors. Current ornithology. New York: Plenum Press; 1996. p. 175-269

Kirk DA, Park AC, Smith AC, Howes BJ, Prouse BK, Kyssa NG, et al. Our use, misuse and abandonment of a concept: whither habitat? Ecol Evol. 2018;00:1-12.

Krebs JR, Wilson JD, Bradbury RB, Siriwardena GM. The second silent spring? Nature. 1999;400:611-2

Kross SM, Kelsey TR, McColl CJ, Townsend JM. Field-scale habitat complexity enhances avian conservation and avian-mediated pest-control services in an intensive agricultural crop. Agric Ecosyst Environ. 2016;225:140-9.

Laake JL. RMark: an R interface for analysis of capture-recapture data with MARK. Seattle: Alaska Fisheries Science Center, NOAA, National Marine Fisheries Service; 2013.

Lee JC, Menalled FD, Landis DA. Refuge habitats modify impact of insecticide disturbance on carabid beetle communities. J Appl Ecol. 2001;38:472-83.

MacKenzie DI, Nichols JD, Lachman GB, Droege S, Royle JA, Langtimm CA. Estimating site occupancy rates when detection probabilities are less than one. Ecology. 2002;83:2248-55.

MacKenzie DI, Nichols JD, Royle AR, Pollock KH, Bailey LL, Hines JE. Occupancy estimation and modeling: inferring patterns and dynamics of species occurrence. Burlington: Elsevier/Academic Press; 2006.

MacKenzie DI, Nichols JD, Royle JA, Pollock KH, Bailey L, Hines JE. Occupancy estimation and modeling: inferring patterns and dynamics of species occurrence. New York: Academic Press; 2017.

Mineau P. Estimating the probability of bird mortality from pesticide sprays on the basis of the field study record. Environ Toxicol Chem. 2002;21:1497-506.

Moorman CE, Bowen LT, Kilgo JC, Sorenson CE, Hanula JL, Horn S, et al. Seasonal diets of insectivorous birds using canopy gaps in a bottomland forest. J Field Ornithol. 2007;78:11-20.

Narosky S, Yzurieta D. Aves de Argentina y Uruguay: Guía de identificación, edición total. Buenos Aires: Vázquez Mazzini Editores; 2010.

Paruelo JM, Guerschman JP, Verón SR. Expansión agrícola y cambios en el uso del suelo. Ciencia Hoy. 2005;15:14-23.

Philpott SM, Soong O, Lowenstein JH, Pulido AL, Lopez DT, Flynn DFB, et al. Functional richness and ecosystem services: bird predation on arthropods in tropical agroecosystems. Ecol Appl. 2009;19:1858-67.
R Core Team. R: A language and environment for statistical computing. Vienna: R Foundation for Statistical Computing; 2013.

Ralph CJ, Geupel GR, Pyle P, Martin TE, DeSante DF, Milá B. Handbook of field methods for monitoring landbirds. Albany: USDA Forest Service General Technical Report PSW-GTR-159; 1996.

Remsen JV Jr, Robinson SK. A classification scheme for foraging behavior of birds in terrestrial habitats. Stud Avian Biol. 1990;13:144-60.

Robinson RA, Wilson JD, Crick HQP. The importance of arable habitat for farmland birds in grassland landscapes. J Appl Ecol. 2001:38:1059-69.

Saluso A, Ermancora O, Anglada M, Toledo C, Borghesan C. Principales invertebrados plagas de la soja y tecnicas utilizadas en la toma de decisiones (Campaña agrícola 2006-2007). Rev Cient Agropecu. 2007;11:153-8.

SIIA. Estimaciones Agrícolas. Datos de la Dirección de Mercados Agrícolas. 2013. https://siia.gov.ar. Accessed 7 Feb 2013.

Solari LM, Zaccagnini ME. Efecto de bordes arboreos y terrazas sobre la riqueza y densidad de aves en lotes de soja de Entre Rios, Argentina. BioScriba. 2009;2:90-100.

Stamps WT, Dailey TV, Gruenhagen NM, Linit MJ. Soybean yield and resource conservation field borders. Agric Ecosyst Environ. 2008;124:142-6.

Standen $\mathrm{V}$. The adequacy of collecting techniques for estimating species richness of grassland invertebrates. J App Ecol. 2000;37:884-93.

Tscharntke T, Clough Y, Wanger TC, Jackson L, Motzke I, Perfecto I, et al. Global food security, biodiversity conservation and the future of agricultural intensification. Biol Conserv. 2012;151:53-9.

Tyre AJ, Tenhumberg B, Field SA, Niejalke D, Parris K, Possingham HP. Improving precision and reducing bias in biological surveys: estimating false-negative error rates. Ecol Appl. 2003;13:1790-801.

Varni VD. Efecto de la aplicación de insecticidas sobre artrópodos fitófagos y predadores en cultivos de soja y sus márgenes en Entre Ríos. Buenos Aires: Licenciate Thesis, Universidad de Buenos Aires; 2010.

Weyland F, Zaccagnini ME. Efecto de las terrazas sobre la diversidad de artrópodos caminadores en cultivos de soja. Ecol Aust. 2008;18:357-66.

Whelan CJ, Şekercioğlu CH, Wenny DG. Bird ecosystem services: economic ornithology for the 21 st century. In: Şekercioğlu CH, Wenny DG, Whelan CJ, editors. Why birds matter: avian ecological function and ecosystem services. Chicago: University of Chicago Press; 2016. p. 1-26.

Whelan CJ, Wenny DG, Marquise RJ. Ecosystem services provided by birds. Conserv Biol. 2008;1134:25-60.

White GC, Burnham KP. Program MARK: Survival estimation from populations of marked animals. Bird Study. 1999;46:120-39.

Wiens JA, Rotenberry JT. Habitat associations of shrubsteppe bird communities. Bioscience. 1981;31:240-1.

Wolda H. Insect seasonality: why? Rev Ecol Syst. 1988;19:1-18.

Zufiaurre E, Codesido M, Abba AM, Bilenca D. The seasonal role of field characteristics on seed-eating bird abundances in agricultural landscapes. Curr Zool. 2017;63:279-86.

Ready to submit your research? Choose BMC and benefit from

- fast, convenient online submission

- thorough peer review by experienced researchers in your field

- rapid publication on acceptance

- support for research data, including large and complex data types

- gold Open Access which fosters wider collaboration and increased citations

- maximum visibility for your research: over $100 \mathrm{M}$ website views per year

At BMC, research is always in progress.

Learn more biomedcentral.com/submissions 